\title{
Ethanol Production from Molasses with Immobilized Cells Technique in Packed Bed Bioreactor by Extractive
}

\author{
Musfil $\mathrm{AS}^{1}$, Tri Widjaja ${ }^{1}$, Ali Altway ${ }^{1}$, and R. Darmawan ${ }^{1}$
}

\begin{abstract}
The aim of this research was to study the effect of total sugar concentration, Ca-Alginate and $\mathrm{K}$ Carrageenan density in immobilized cells on packed-bed and batch bioreactor performance for ethanol production. In addition, this research was also aimed to study the effect of solvent flow rate on packed column performance expressed as $\%$ extraction recovery. This experiment was carried out with total sugar concentration of 10, 14, $18 \%(\mathrm{v} / \mathrm{v})$ and immobilized cells Ca-Alginate and K-Carrageenan at a density of $2 \%(w / v)$ with amyl alcohol as solvent. Based on the result of this study, it is concluded that the total sugar concentration influenced the concentration, yield and productivity of ethanol. The result of this study for immobilized Ca-Alginate cells showed that the maximum ethanol product concentration, yield and productivity were $\mathbf{7 . 2 8 \%}$ g/l, 57.48 g/l, 38.22\%, 71.85 g/l.hr, respectively. Meanwhile, immobilized K-Carrageenan cells showed the maximum ethanol product concentration, yield and productivity as $7.22 \% / 56.99 \mathrm{~g} / \mathrm{l}, \mathbf{2 6 . 7 3 \%}$, and $68.40 \mathrm{~g} / \mathrm{l} . \mathrm{hr}$, respectively. In extraction process, increasing amyl alcohol solvent flow rate will increase mass transfer and hence increase ethanol recovery.
\end{abstract}

Keywords—ethanol, extraction, immobilized cells, packedbed bioreactor

\section{INTRODUCTION}

A $\mathrm{s}$ we know that immobilized cells is a process to halt the movement of enzyme molecules or a cell that held in a catalyzed reaction. This immobilization of cell is done because of the size of the microorganisms are too small and it has a density close to the density of water, therefore, it has a possibility to be bonded while in product stream. The advantages in using immobilized cell than free cells are the ease to separate the product, high volumetric productivity, increase the process control and decrease the contamination, lessen separation cost, and prevent wash out occurred in product stream. Among various immobilized techniques, trapping cell in calcium-alginate gel system is the simplest method and it does not have poisonous property. Immobilized cell technique with $\mathrm{Ca}$-alginate was developed by which involved drop-wise cell suspension in sodium alginate that hardened [3]. This method also ease to apply with various cells for example bacteria, cynobacteria, algae, and yeast fungi. In research, we can use agitated bioreactor (continous flow stirer tank), fluidized bed reactor, and packed bed reactor, but the researcher recommended to use packed bed reactor because of cost consideration, it is easy to operate and it can be operated automatically in industries.

\footnotetext{
${ }^{1}$ Musfil AS, Tri Widjaja, Ali Altway, and R. Darmawan are with Department of Chemical Engineering, FTI, Institut Teknologi Sepuluh Nopember, 60111, Indonesia. E-mail: kajur_tkimia@its.ac.id.
}

In this research, we use zymomonas mobilis because it is a Gram-negative bacterium that has been attractive for fuel grade ethanol production. It is an osmo and ethanoltolerant bacterium and it has shown higher specific rates of glucose uptake and ethanol production via the EntnerDoudoroff pathway under anaerobic conditions[2].

Conventional fermentation processes have some weaknesses. First, it commonly uses batch process to easily control the fermentation process from microorganism contamination. Second, the ethanol concentrations produced are so low because the accumulated produced ethanol will poison microorganism while fermenting. The accumulation of dissolved product which is poisonous will slowly decrease or even halt microorganism growth (Minier and Goma, 1982). There is a process limit in conventional process such as ethanol inhibition, in ethanol concentration for $12 \%(\mathrm{v} / \mathrm{v})$ fermented broth, specific microorganism growth and specific rate production will decrease and cell density in packed bed column will be low, therefore the sugar solution is not completely fermented. In order to increase ethanol productivity, we have to remove the inhibiting content during fermentation.

Because ethanol is more volatile than water, there is a concept to implement ethanol water separation technique using ethanol distillation in vacuum during fermentation. This technique has a purpose to remove the ethanol inhibition. The researchers (Minier and Goma, 1982) have researched fermentation technique in vacuum condition, with cell recycle. It increases ethanol production up to 82 $\mathrm{g} / \mathrm{l}$.hr, while without cell recycle, the produced ethanol was only $40 \mathrm{~g} / \mathrm{l} . \mathrm{hr}$ and if we compare to conventional process, the produced ethanol is only $29 \mathrm{~g} / \mathrm{l} . \mathrm{hr}$. Unfortunately, the energy cost to produce azeotrope ethanol is 1.05 times the cost needed for conventional batch process.

Logic approach to increase ethanol productivity in packed bed bioreactor is by extractive fermentation where formed ethanol is extracted by organic solvent. Extractive fermentation has more advantages such as ease of ethanol recovery and purifying process, it replaces azeotrope distillation method which was commonly used to separate ethanol from dilute fermented broth. Since this process can reduce the obstruction of microorganism growth by poison from the ethanol product, therefore, the solution with high glucose content can be used as fermentation feed.

\section{MethodolOGY}

The research stages are as follows: molasses pretreatment, culture development, starter, immobilized cells and fermentation, and extraction process. 


\section{A. Immobilized Cells Preparation}

It can be done by bead forming with Ca-Alginate and $\mathrm{K}$-Carrageenan as supporting matrices. The concentration of Ca-Alginate and K-Carrageenan is $2 \%$.

\section{B. Fermentation Process}

It is begun by inputting immobilized cells bead into packed bed bioreactor tray according to the concentrations. And then the sterilized molasses that content a total sugar concentration according to the variables was fed into packed bed bioreactor with rate $0.06 \mathrm{l} / \mathrm{hr}$ and dilution rate $1.2 \mathrm{hr}^{-1}$.

\section{Extraction Process}

Broth which is yielded from fermentation process was contacted with solvent by flowing it from upper packed column and controlling the broth rate and the solvent rate. Thus, liquid that flowing from the upper packed column is called extract and liquid that flowing from the lower packed column is rafinate. In order to analyze extract, Gas Chromatography (GC) was used. The schematic diagram of equipment rigs being used is shown below:

TABLE 1.

\begin{tabular}{ccc} 
& RESEARCH INFORMATION & \\
\hline Information & $\begin{array}{c}\text { Continuous } \\
\text { Fermentation }\end{array}$ & $\begin{array}{c}\text { Batch } \\
\text { Fermentation }\end{array}$ \\
\hline $\begin{array}{c}\text { Bioreactor } \\
\text { Reactor Volume } \\
(\mathrm{ml})\end{array}$ & Packed bed & Batch Stirer \\
Bead & 258 & 1800 \\
$\begin{array}{c}\text { Bead weight }(\mathrm{g}) \\
\text { Residence time } \\
(\mathrm{hr})\end{array}$ & $\begin{array}{c}\text { Ca-Alginate/ } \\
\text { K-Carrageenan }\end{array}$ & Free Cells \\
\hline
\end{tabular}

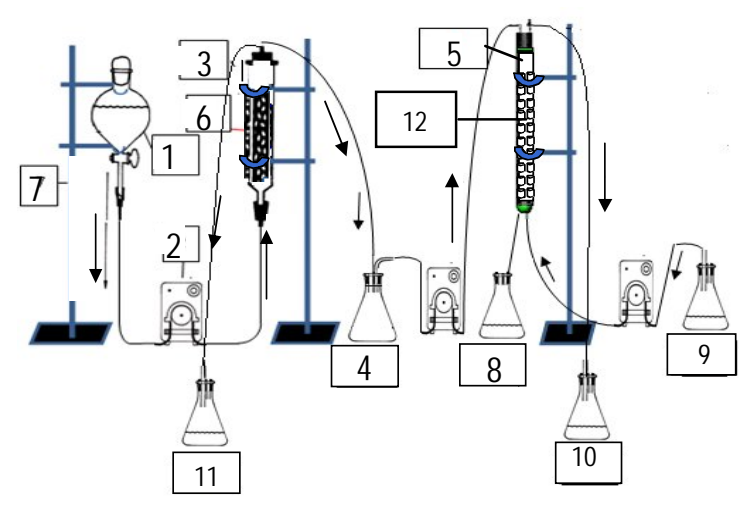

Fig. 1. Continuous packed bed bioreactor equipments

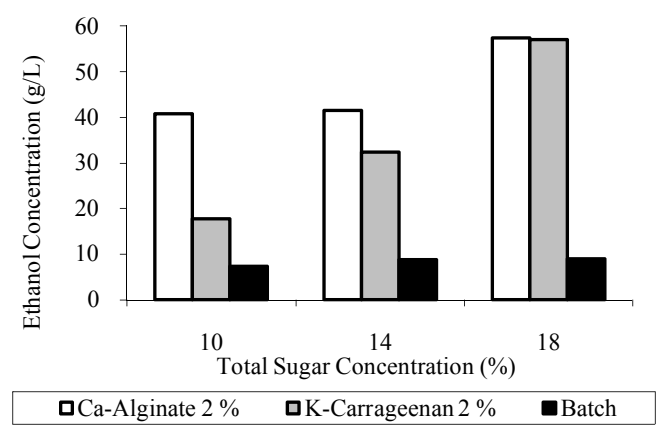

Fig. 2. Effect of total sugar concentration on ethanol concentration
The equipments:
1. molasses

2. peristaltic pump

3. packed bed bioreactor

4. fermented broth

5. extractor

6. immobilized cells
7. stative

8. rafinate

9.solvent

10.extract

11. $\mathrm{CO}_{2}$ container

12.raschig ring

\section{RESULTS AND DISCUSSION}

The continued fermentation experiment is begun by filling up the packed column with the Ca-Alginate or KCarrageenan bead until it is fully filled. Furthermore, by peristaltic pump the molasses was pumped down through silicon tube to packed bed bioreactor with $0.06 \mathrm{l} / \mathrm{hr}$ flow rate and $1.2 \mathrm{hr}^{-1}$ dilution rate, and ethanol as product flowing out from the liquid effluent stream on the upper of bioreactor. While the batch fermentation is taking on batch stirrer reactor equipped with jacket and constant rpm agitator's speed rotation. Continued fermentation and batch fermentation experimented in $\mathrm{pH} 4-5$. The Gas Chromatography method is used to analyze the ethanol products and the Optical Density method is used to analyze the free cells from batch fermentation. Table 1 below show research information for continued fermentation and batch fermentation.

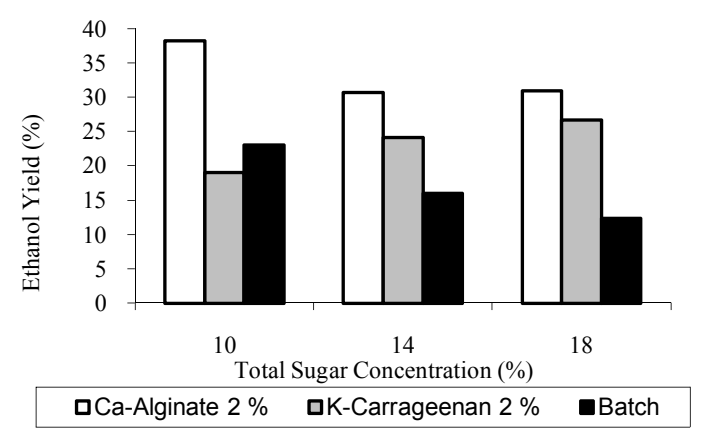

Fig. 3. Effect of total sugar concentration on ethanol yield

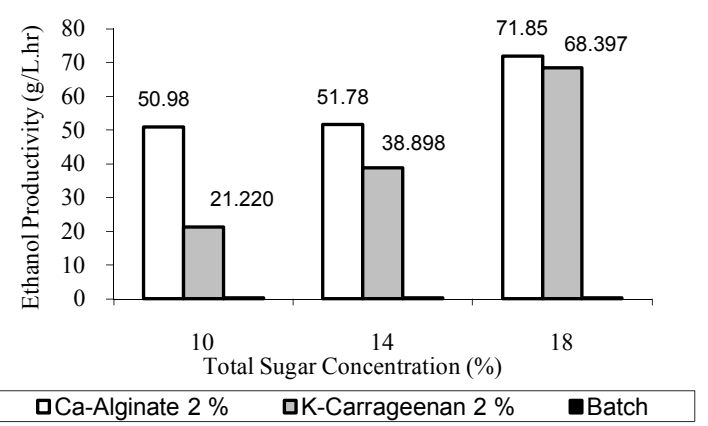

Fig. 4. Effect of total sugar concentration on ethanol productivity

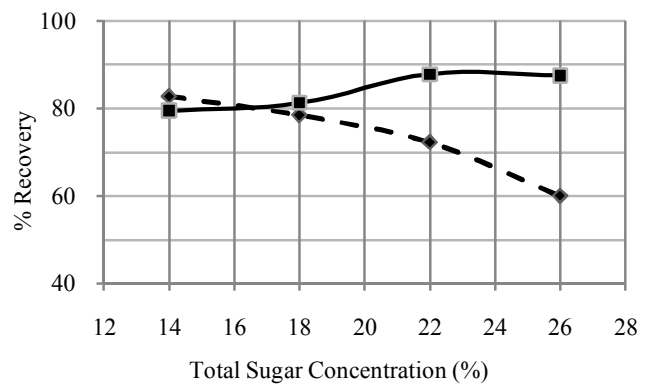

- $\downarrow$ Broth rate $=0,09 \mathrm{~L} / \mathrm{hr} \longrightarrow$ - Broth rate $=0,15 \mathrm{~L} / \mathrm{hr}$

Fig. 5. The relationship between glucose concentrations and $\%$ recovery with $\mathrm{V}_{\mathrm{B}} / \mathrm{V}_{\mathrm{S}}=1 / 1$ 


\section{A. The Effect of Total Sugar Concentration on Ethanol Production}

The relationship between average ethanol concentrations and various glucose concentrations with $2 \%$ bead Ca-Alginate and 2\% K-Carrageenan is shown in Fig. 2. The ethanol concentrations produced for $2 \%$ bead Ca-Alginate are $40.78 \mathrm{~g} / 1 ; 41.43 \mathrm{~g} / 1$ and $57.48 \mathrm{~g} / 1$ while the ethanol concentrations produced for $2 \%$ bead K-Carrageenan are $17.68 \mathrm{~g} / \mathrm{l} ; 32.41 \mathrm{~g} / \mathrm{l}$ and $56.99 \mathrm{~g} / \mathrm{l}$. The ethanol concentrations produced for batch fermentation process are $7.39 \mathrm{~g} / 1 ; 8.84 \mathrm{~g} / \mathrm{l}$, and $8.92 \mathrm{~g} / \mathrm{l}$.

The average highest ethanol concentration reached for $2 \%$ bead Ca-Alginate and $18 \%$ glucose concentration is $57.48 \mathrm{~g} / 1$ and then the average highest ethanol concentration reached for $2 \% \mathrm{~K}$-Carrageenan and $18 \%$ glucose concentration is $56.99 \mathrm{~g} / \mathrm{l}$. In $2 \%$ bead Ca-Alginate and $2 \%$ K-Carrageenan, the higher glucose concentration served the higher ethanol concentration produced. It is caused by the amount of substrates from glucose that is converted into ethanol as product are higher. While for batch fermentation process, $8.92 \mathrm{~g} / 1$ is the highest ethanol concentration reached for $18 \%$ glucose concentration. Ethanol concentration produced batch fermentation lower than that produced of continued fermentation which using immobilized cell. Since the glucose concentration was high, the substrat then became an inhibitor and so cause to high osmosis (Barros, et al, 1987) then occurred, causing cell membrane to ruptured decreasing cell number, thus decreasing the ethanol produced.

\section{B. The Effect of Total Sugar Concentration on Ethanol Yield}

Yield is the comparison between ethanol produced and glucose consumed during fermentation reaction. Fig. 3 shows the relation between ethanol yield average (\%) and glucose concentration in molasses (\%).

Fig. 3 shows that the highest ethanol yield reached for $2 \%$ bead Ca-Alginate and $10 \%$ concentration of substrate is $38.22 \%$ and then the highest ethanol yield reached for $2 \%$ bead K-Carrageenan and 18\% concentration of substrate is $26.73 \%$. While for batch fermentation process, it is reached for $10 \%$ concentration of substrate. The increase of glucose concentration does not affect on the amount of the ethanol yield, for immobilized cells that use Ca-Alginate bead, the more concentration of glucose used the less ethanol yield produced and for immobilized cells that use K-Carrageenan bead, the more concentration of glucose used the more also ethanol yield produced. While for batch fermentation process, the more concentration of glucose used the less ethanol yield produced.

\section{The Effect of Total Sugar Concentration on Ethanol Productivity}

In fermentation, productivity is stated as grams ethanol product/liter/hours. Fig. 4 shows the relationship between ethanol productivity average (g/l.hr) and concentration of glucose in molasses (\%).

According to the results from the experiments, Fig. 4 shows us the ethanol productivities are $50.98 \mathrm{~g} / \mathrm{l} . \mathrm{hr}$; $51.78 \mathrm{~g} / 1 . \mathrm{hr}$ and $71.85 \mathrm{~g} / \mathrm{l} . \mathrm{hr}$ for $2 \%$ bead Ca-Alginate at $10 \%, 14 \%$, and $18 \%$ total sugar concentrations and then the ethanol productivities produced are $21.22 \mathrm{~g} / \mathrm{l} . \mathrm{hr}$, $38.89 \mathrm{~g} / \mathrm{l} . \mathrm{hr}$, and $68,40 \mathrm{~g} / \mathrm{l} . \mathrm{hr}$ for $2 \%$ bead $\mathrm{K}$ Carrageenan. While in batch fermentation, the ethanol productivities produced are $0.15 \mathrm{~g} / 1 . \mathrm{hr} ; 0.16 \mathrm{~g} / \mathrm{l} . \mathrm{hr}$, and $0.17 \mathrm{~g} / 1 . \mathrm{hr}$ for $10 \% ; 14 \%$, and $18 \%$ total sugar concentrations. Ethanol productivity is directly proportional to ethanol concentration because ethanol productivity is ethanol concentration divided by residence time. According to the results from the experiments, immobilized cells with $\mathrm{Ca}$-Alginate supporting matrices has higher yield and ethanol productivity than immobilized cells with K-Carrageenan supporting matrices. It is because the differences in the treatment to generate for those CaAlginate and K-Carrageenan bead. In the generation of $\mathrm{Ca}$-Alginate bead does not need heating process (only room temperature $/ 30^{\circ} \mathrm{C}$ needed), while K-Carrageenan bead needs heating up to $70^{\circ} \mathrm{C}$ and it was decreased until $40^{\circ} \mathrm{C}$. The heating process at this temperature is causing death of some bacteria then the concentration of ethanol is lessening because the amount of bacteria is decreasing.

From the concentrations side, yield and productivity of ethanol in continued fermentation process is better than in batch fermentation process. Immobilized cells $\mathrm{Ca}$ Alginate and K-Carrageenan are used in continued fermentation as supporting matrices, where zymomonas mobilis bacteria is trapped in the beads. It makes gradient of glucose, that following the lower glucose concentrations which will become non inhibitor (Barros, et al, 1987). While in batch fermentation process, the zymomonas mobilis is free (free cells), it is causing the membrane plasma breaks out of its cell wall membrane so that the substrates, inhibitor characterized to cell, caused the decreasing of fermentation rate [3].

\section{The Effect of Broth Rate and Solvent Rate on \% Recovery}

The volumetric ratio we used in extraction process between broth rate and solvent rate is $1: 1$. We used amyl alcohol as solvent and raschig ring type as packing bed. The extraction process itself takes 12 hours, after that the samples and the rafinate are being taken so we can analyze the ethanol concentration with Gas Chromatography Method. Fig. 5 shows the relation between glucose concentration $(\%)$ and $\%$ recovery with ratio of broth rate $\left(\mathrm{V}_{\mathrm{B}}\right)$ : amyl alcohol rate $\left(\mathrm{V}_{\mathrm{S}}\right)=1: 1$.

For $0.15 \mathrm{l} / \mathrm{hr}$ broth rate the \% recovery tends to increase then it is stable, at increasing glucose concentration increasing, the highest \% recovery is $89.55 \%$ for $22 \%$ glucose concentration. While for $0.09 \mathrm{l} / \mathrm{hr}$ broth rate the $\%$ recovery tends to decrease, at increasing glucose concentration. The highest \% recovery is $84.43 \%$ for $14 \%$ glucose concentration. According to Fig. 5, it is known that we get higher \% ethanol recovery for 0.15 $1 / \mathrm{hr}$ broth rate than for $0.09 \mathrm{l} / \mathrm{hr}$ broth rate. It also shows that the faster amyl alcohol (solvent) flow into column, the higher \% recovery resulted, it's caused by increasing of mass transports because of the increasing rate of solvent, therefore, the amount of extracted ethanol and the value of $\%$ recovery are increasing.

\section{CONCLUSION}

Immobilized cells Ca-Alginate gave a higher concentration, yield and productivity ethanol than those of immobilized cells of K-Carrageenan. The results of this study for immobilized Ca-Alginate cells showed the maximum ethanol product concentration, yield and productivity were $7.28 \% / 57.48 \mathrm{~g} / 1,38.22 \%$, and 71.85 
g/l.hr, respectively. Meanwhile, immobilized K-Carrageenan cells showed the maximum ethanol product concentration, yield and productivity were $7.22 \% / 56.99 / 1$, $26.73 \%$, and $68.40 \mathrm{~g} / \mathrm{l} . \mathrm{hr}$, respectively. The batch fermentation production showed that the result of aforementioned parameters were $8.92 \mathrm{~g} / 1$ (1.13\%), 23.09\%, 0.17 $\mathrm{g} / \mathrm{l}$.hr, respectively. It was found that the concentration, yield, and productivity of ethanol using a continuous fermentation method was better than using a batch ones. In extraction process, increasing amyl alcohol solvent flow rate will increase mass transfer and hence increase ethanol recovery.

\section{FUTURE WORKS}

In this research, process of extractive-fermentation was separated. To reducing ethanol poison effect, it is necessary to conduct extractive fermentation simultaneously in one equipment or the two process conducted in two separated equipment but in close system by recycle

\section{ACKNOWLEDGMENT}

This project was granted by "Penelitian Guru Besar 2010" by Institution Research and Public Services of ITS (LPPM-ITS), under contract Number: 0892/I2.7/PM/ 2010 July 1, 2010 and by Hibah Bersaing by Directorate
Research and Public Services, Directorate General of Higher Education (DIKTI) Department of National Education Republic of Indonesia under contract Number: 042/SP2H/DP2M/ III/2010 March 12010 for financial support. The authors would like to thanks Teddy Apri Riantiarno, Yanu Pamungkas, Nur Fauziah Arini, Winda Savitri, E. Topan Ardiansyah, and Natalia Hariani for their contribution to this experiment.

\section{REFERENCES}

[1] M.R.A. Barros, J.M.S Cabra, and J.M.Novais, 1987, "Production ethanol by immobilized Saccharomyces Bayanus in an extractive fermentation system", Biotechnology and Bioengineering $\mathrm{Vol}$ XXIX pp. 1097-1104.

[2] M.L. Cazetta, M.A.P.C. Celligoi, J.B. Buzato, and I.S. Scarmino, 2007, "Fermentation of molasses by Zymomonas mobilis : Effects of temperature and sugar concentration on ethanol production", Bioresource Technology, 98, 2824-2828.

[3] Y. Goksungur and N. Zorlu, 2001, "Production of ethanol from beet molasses by Ca-Alginate immobilized yeast cells in a packedbed bioreactor", Turk Journal of Biology, 25, pp. 265-275. Turkey.

[4] W. Grote, K.J. Lee, and P.L Rogers, 1980, Continuous ethanol production by immobilized sels of Zymomonas mobilis, Biotechnology Letters vol. 11, pp. 481-486.

[5] Margaritis,A., P.K. Bajpai, and J. Wallace, 1981, "High ethanol productivities using small Ca-Alginate bead of immobilized sels of zymomonas mobilis", Biotechnology Letters, Vol. 3, No 11, pp. $613-618$.

[6] Minier, M, and Goma, G, (1982)", Etanol production by extractive fermentation", Journal of Biotechnology and Bioengineering, 34, pp. 1565-1579. 